\title{
How Fit Are the Person and Organization at UIN Jakarta?
}

\author{
Ikhwan Lutfi \\ Psychology Faculty of UIN Syarif Hidayatullah Jakarta, Kertamukti Street, no 5, Cirendeu, \\ Tangerang Selatan, Banten
}

\begin{abstract}
This study aims to get a picture of the compatibility between people and organizations (Person Organization Fit / POF) in the scope of UIN Jakarta. POF is conformity between people and the organization, through values, culture, and satisfaction. The quantitative method by analysing the description and different tests of 222 respondents obtained by a non-probability sampling of lecturers, employees and UIN students. Different test for UIN members shows that there is a compatibility between the members' values and the values owned by UIN as an organization, besides that there are no differences in values held by UIN group members from all elements.
\end{abstract}

Keywords: organization, person, values, culture, satisfaction. 


\section{Introduction}

Conformity between employees and the organization (person organization fit / POF) is the most important thing to realize organizational goals). Organizations with high POF are able to maintain employee commitment [1], [2], [3] and build positive perceptions of the organization [4]

POF illustrates the correspondence between organizational values and individual values [2],[5]. Individual suitability with organization includes motivation, characteristics / background [6], [7], [8], [9] attributes [2] feelings and perception [2].

Research on POF has provided benefits in several ways. The first is motivation to increase employee satisfaction and commitment to the company, individual outcomes that have implications for sustainable strategic growth for the company's suitability and retain employees in the long run with [2], [7], [8]. Second, as an evaluation of what an organization has not yet developed due to a lack of conformity between employees and the organization or low POF [10] [11].

UIN Jakarta as an organization requires a high POF for several reasons. First is the big goal to become a World Class University that begins with the change from teaching university to research university. Changes in cultural paradigms and academic traditions that were originally in the form of mentoring, discussions on the development of teaching materials, practicum, training and workshops, changed towards discussing research with scientific conference media, writing scientific publications, and launching new findings.

The consequences of changes in academic culture have an impact on the change and preparation of facilities, namely discussion space for researchers, strengthening communication networks and networking with various tertiary institutions. Besides that, the main change as a consequence of research universities is the learning process. Where research and learning go hand in hand and in line. Research is no longer independent of the learning material to be provided. The results of the study become teaching material for lectures. Parties affected by this implication are of course the teaching staff (lecturers). Other parties who were affected by the change to a research university were education staff (employees or staff).

The use of adequate information technology requires competent employees. Because education and teaching based on information technology demands speed and determination in work. The next party to adjust the status of the research university is students. Demands to students are no longer just learning from books, journals, or other references, but the ability to link learning material with research results also plays an important role. In other words, the change to a research university had an impact on the entire academic community at UIN Jakarta.

Based on the description above, it is important to know how is the compatibility between the UIN Jakarta academic community (lecturers, staff, and students) with the UIN Jakarta organization. Based on POF theory proposed by Kristof, the suitability of UIN Jakarta can be seen in 4 (four) terms [2]. The first is the value congruence of the academic community with the value of UIN Jakarta. Namely the suitability of the values held by the UIN Jakarta academic community with the values of knowledge, piety and integrity. The second is the compatibility between the vision, mission and objectives of UIN Jakarta and the understanding of its citizens. Third is the level of satisfaction of UIN Jakarta residents towards the services of the system and organizational structure.

Fourth is the silence between the culture of UIN Jakarta as a research university and the characteristics of its members (culture personality congruence). That choosing people who have personalities equal to organizational values will create a flexible attitude of workers [1]. 
Chadwell and O'Reilly tested the congruence of individuals and organizations with performance, they found that POF was positively and strongly related to job satisfaction and performance [8]. The same thing was stated by Barrett [12]; Tziner [8]. However, research conducted by Aurthy \& Daugherty [13] who examined the relationship of POF with job satisfaction in warehouse employees (warehouses) in England and Spain found insignificant results. There is no correlation between POF for the dimensions of conformity between coworkers and satisfaction. What can be identified is the lack of interaction between employees.

\section{Person Organization Fit}

Person organization Fit (POF) is broadly defined as compatibility between organizations and employees or individuals [2]. Sekiguchi identified POF in four domains [14].

Bowen et., Al argue that choosing people whose personalities are equal to organizational values will create a flexible work attitude. In the POF review [1], Kristof [2] proved empirically that P-O Fit is a strong predictor of job satisfaction and organizational commitment [6] [7] [8].

People-organization fit is defined here as a fit between the norms and values of the organization and the values of people. In order to determine the impact that organizational membership will have on individual values and behavior and the effect that an individual will have on the organization's norms and values, we must first assess the extent of the agreement between one's values and organizational values. In addition, many of the interactional studies discussed earlier have examined personality traits as important determinants of behavior.

Second, a distinction is made between P-O fit and other types of P-E suitability to describe what is not included in the construct Hakim \& Ferris [10]; Schwab, [11]. Three additional categories of congruence are presented, each dealing with compatibility between people and environmental aspects: vocation, group, or work. This brief overview of the types of person-environment fit is presented to establish clear boundaries of the P-O fit constuct.

Based on the understanding of the POF, the researchers use the appropriateness of values as operational of the PO Fit because (1) values are fundamental and maintain the characteristics of individuals and organizations [7] and (2) values predict a number of outcomes individuals which include satisfaction and purposeful behavior [15].

POF can be interpreted in four concepts [2]. First is the value congruence, is the suitability between the intrinsic value of individuals and organizations [6],[7],[14],[16],[17] defines the concept of value as "certain beliefs of behavior or existence personally or socially better for opposing or opposite modes of behavior or end-state existence". Principle values are the foundation of values and actions based on integrity. Types of values include ethical / moral values, (religious, political) teachings / ideological values, social values, and aesthetic values. Values can be seen as hierarchical in nature, which leads to the failure of the value system. One set of values is called a value system. Values are deeply related and seeing one's values separately and freely from one another cannot meaningfully explain attitudes and behavior. value systems tend to form early in life and are very stable. Large longitudinal studies of values have generally shown remarkable stability [17]. One who values obedience does not believe that it is better to be disobedient than to be obedient. Changes in the relative value system require structuring the interests given to various values [18]. According to the aspect of additional fit, the value of congruence is the suitability between individual values and values in 
effect in organizations. Conformity between personal values and organizational values is also referred to as person-culture fit [2].

The suitability of the goal (goal congruence), is the suitability between the goals of the individual and the organization in this case is the leader and co-workers [9,14] Goal congruence is the harmony between individual actions to achieve personal goals to help achieve organizational goals. In an organization, human behavior must be influenced by the formal system (which is formed by the organization) and informal (work ethic, management style and culture).

\section{Procedure}

The population of this research is the academic community of the State Islamic University (UIN) Syarif Hidayatullah Jakarta consisting of lecturers, employees and students. Lecturers and employees are those who are registered as people who work at UIN Syarif Hidayatullah Jakarta, both as civil servants (civil servants) as well as employees and lecturers of non-PNS UIN. Students are those who have a student identity card (KTM) UIN Syarif Hidayatullah Jakarta.

The quantitative approach was used in this study by using the POF questionnaire as a tool to collect data. Analysis of the data that has been collected is done by descriptive analysis and testing the different POF scores between groups of respondents. To get respondents, non-probability sampling techniques are used by accidental sampling, the sample that fills the questionnaire is a member of the population that is accidentally encountered in the field. The probability of choosing a member of the population to be sampled due to the factor of the sample meeting with the researcher. Researchers asked 350 people to fill out the questionnaire, but those who filled it according to the procedure were 250 questionnaires, and which could be used for analysis as many as 222 respondents. POF measurement tools are taken from the theory created by Kirchoff, then validated by using the CFA technique with the help of Lisrell software. Of all POF items, there are no dropped items because they are all valid.

\section{Results And Analysis}

Before analyzing quantitatively, researchers conducted a qualitative study to get a picture of the values that exist in the UIN Jakarta environment. This qualitative research was conducted by asking open- ended questions on the research subjects. The open- ended question basically wants to explore the response in the form of thinking of research subjects about what stands out from UIN Syarif HIdayatullah Jakarta.

The values possessed by respondents are religiosity, relationships between people, professionalism and the desire to serve. On the other hand, there are a lot of opinions about things around campus, ranging from infrastructure, bureaucracy, non-academic activities to academic activities, such as the quality of the teaching lecturers in the academic field. For more complete information, as listed in the table below.

\begin{tabular}{clc} 
Table 1 & \\
\hline No & $\begin{array}{l}\text { Dimension of } \\
\text { Organization }\end{array}$ & $\begin{array}{c}\text { Total } \\
\text { responden }\end{array}$ \\
\hline 1 & $\begin{array}{l}\text { Islamic and religious } \\
\text { atmosphere }\end{array}$ & $57 \%$ \\
2 & strategic and accessible & $95 \%$ \\
3 & services, both academic & $69 \%$ \\
4 & and non-academic & $78 \%$ \\
5 & Tuition fee & $5 \%$ \\
6 & Facilities & $69 \%$ \\
7 & Oopitality and tolerance & $88 \%$ \\
& Organization and & $90 \%$ \\
\hline
\end{tabular}


According to the data table, can be explained As many as $57 \%$ of respondents feel that UIN Jakarta has a high Islamic, religious and religious atmosphere. most of the responden think that with the label of UIN Syarif Hidayatullah Jakarta as an Islamic University, Islamic, religious and religious nuances can be seen reinforced by the attire of both lecturers and students in accordance with Islamic law and the existence of organizations that contain religious and Islamic elements.

Then the respondents' opinions regarding the strategic and easily accessible layout of UIN Jakarta were $95 \%$ of respondents. Respondents assumed that they saw the location of UIN Syarif Hidayatullah Jakarta close to the terminal and station toll road access and also in the DKI Jakarta area

The opinion of respondents regarding services, both academic and non-academic as well as adequate infrastructure and tends to be more complete than UIN in other regions, as many as $69 \%$ of respondents, This is seen more quickly the renovation and development in the UIN Syarif Hidayatullah Jakarta area, and already seen the UIN development mockups, as seen in the lobby of the UIN Syarif Hidayatullah Jakarta some of Faculty of.

The next factor is tuition, in this factor as many as $78 \%$ of respondents stated that tuition is very affordable. In general, tuition fees at UIN are cheaper than universities around Jakarta.

One of the worst dimensions is facilities, especially parking facilities as much as $5 \%$ of respondents were satisfied or $95 \%$ respondent dissatisfied. This dissatisfaction with facilities, especially parking spaces, is caused by the very limited parking area and parking financial transparency. This is also due to the large number of respondents, especially on Campus 1, where students bring quite a lot of vehicles because there is a university center and many faculties therein, and the University is not ready to provide different parking spaces as is the case with Campus 2.

As many as $69 \%$ of respondents stated that hospitality and tolerance are prominent in UIN Jakarta. All components at UIN display polite and friendly and very tolerance. The enabling factor for this condition is the expression of Islamic values and eastern culture of courtesy.

As many as $88 \%$ of respondents feel that various organizations at UIN have interesting and beneficial activities to participate in and engage in. It can be seen that many campus organizations provide a place to express the interests and talents of students. Then, regarding the quality of lecturers at UIN Jakarta as much as $90 \%$ of respondents think that the lecturers are qualified, competent and professional in their fields.

The results of the different test calculations show no differences in the value of Knowledge, piety, and integrity, values, goals and needs, and culture between students and lecturers / employees. That is, all the things that are needed by the organization are not translated and interpreted differently by community members.

There is no significant difference in the value of knowledge between students and lecturers and employees. This shows that the academic community has the same goal, which is to make UIN Sarif Hidayatullah Jakarta a leading university in developing knowledge. There is no significant difference in piety scores between students and lecturers and employees. This shows that each unit in an institution similar to UIN Syarif Hidayatullah Jakarta has been able to internalize each Islamic value that is upheld.

There is no significant difference in the value of integrity between students and lecturers and employees. This shows that each element perceives UIN Syarif Hidayatullah as an institution that has a good level of integrity. 
There is no difference in the perception of the suitability of values between students and lecturers and employees. This shows that the values possessed by each element of the organization are in line alias fit. There is no difference in perception regarding the suitability of the objectives between students and lecturers and employees. This shows that both students and lecturers and employees have the same goals in this organization. There is no difference in perception about meeting the needs of students and lecturers and employees. This means that there are gaps in meeting the needs in UIN Syarif Hidayatullah Jakarta. There is no difference in organizational culture between students and lecturers and employees. This shows that every element in UIN Syarif Hidayatullah Jakarta has the same organizational culture.

The results of this study imply several things. First, the motto of UIN Syarif Hidayatullah Jakarta "Knowledge, Piety, Integrity" has been able to be understood by most elements of the UIN Syarif Hidayatullah Jakarta academic community. This is important, because the same motto will strengthen an organization to achieve its goals. With the realization of these ideals, it will further strengthen UIN Syarif Hidayatullah Jakarta as an institution that has a unique identity and one goal.

Second, in general, almost all aspects of person- organization fit are found to be suitable among the academic community of UIN Syarif Hidayatullah Jakarta, namely the suitability of values, suitability of goals, and suitability of personal culture. An important value equation becomes an identity for an organization to be unique. At UIN Jakarta itself, it has always been known as an Islamic and religious campus, and this value has remained well internalized throughout all circles until now. This is certainly good for the existence of an Islamic institution in the international world.

But behind that, meeting needs is still a classic problem at UIN Syarif Hidayatullah Jakarta. The gap between the perception of meeting the needs between students and lecturers and employees is still a polemic. For students, it is certainly beneficial because it is always affordable to be able to get facilities that are not inferior to expensive universities. another thing with employees and lecturers, who still often complain about salaries and benefits that are not in accordance with the workload required every day. Classic problems such as parking services and bureaucracy are also still pretty much complained by respondents. This of course could hamper the progress of UIN Syarif Hidayatullah Jakarta to have a prosperous academic community.

\section{References}

[1] Bowen D. E., Ledford, G. E., \& Nathan, B. R. 1991. Hiring for the organization, not the job. Academy of Management Executive, 5 (4), 35-49.

[2] Kristof, A. L. 1996. Person-organization fit: an integrative review of its conceptualizations, measurement, and implications. Personnel Psychology 49, 1-49.

[3] Mahardhika, G., 2006. Pengaruh Person-Organization Fit (Kecocokan Nilai-Nilai Individu Dengan Nilai-Nilai Organisasi) Terhadap Kepuasan Kerja, Komitmen Organisasional dan Kinerja Karyawan (Studi Pada PKU Muhammadiyah Pekalongan). 104.

[4] Yaniv, E., \& Farkas, F. (2005). The impact of person-organization fit on the corporate brand perception of employees and of customers. Journal of Change Management, 5(4), 447-461. https://doi.org/10.1080/14697010500372600

[5] Valentine, S., Godkin, L., Lucero, M., 2002. Ethical Context, Organizational Commitment, and Person-Organization Fit. Journal of Bussiness Ethics, 41, 349-360. 
[6] Boxx, W. R., Odom, R. Y., \& Dunn, M. G. 1991. Organizational values and value congruency and their impact on satisfaction, commitment, and cohesion: an empirical examination within the public sector. Public Personnel Management, 20 (1), 195-205.

[7] Chatman, J. A. 1991. Matching people and organizations: selection and socialization in public accounting firms. Administrative Science Quarterly, 36,459-484.

[8] O'Reilly, C. A., Chatman, J. A., \& Caldwell, D. F. 1991. People and organizational culture: a profile comparison approach to assessing personorganization fit. Academy of Management Journal, 34 (3), 487-516

[9] Vancouver, J. B., \& Schmitt, N. W. 1991. An exploratory examination of person organization fit: organizational goal congruence. Personnel Psychology, 44, 333-352.

[11] Schwab, D. (1980) Construct Validity in Organizational Behavior. Research in Organizational Behavior, 2, 3-43.

[12] Barret, K. (1995). A functionalist approach to shame and guilt. The Guilford Press. Colorado State University

[13] Autry, C. W., \& Daugherty, P. J. (2003). Warehouse Operations Employees: Linking Person Organization Fit, Job Satisfaction, and Coping Responses. Journal of Business Logistics, 24, 171-197.

[14] Sekiguchi, Tomoki. 2004. Person Organization Fit and person Job Fit in Employee Selection: A Review of The Literature. Osaka Keidai Ronshu, Vol.54 No. 6, 179-196.

[15] Meglino, B. M., Ravlin, E. C., \& Adkins, C. L. 1989. A work values approach to corporate culture: a field test of the value congruence process and its relationship to individual outcomes. Journal of Applied Psychology, (3), 424-432.

[16] Chatman, J. A. 1989. Improving interactional organizational research: a model of person- organization fit. Academy of Management Review, 14 (3), 333-349

[17] Bretz, R. D. Jr., \& Judge, T. A. 1994. Person organization fit and the theory of work adjustment: implications for satisfaction, tenure, and career success. Journal of Vocational Behavior, 44, 32-54.

[17] Rokeach, M., \& Ball-Rokeach, S. J. (1989). Stability and change in American value priorities, 1968-1981. American Psychologist, 44(5), 775-784.

[18] Krishnan, V.R., 2008. Does Management Education Make Students Better Actors? A Longitudinal Study of Change in Values and Self-Monitoring. Great Lakes Herald, 2 (1): 36-48. 